\title{
Depression Among Patients with Type 2 Diabetes Mellitus: Prevalence and Associated Factors in Hue City, Vietnam
}

This article was published in the following Dove Press journal: Diabetes, Metabolic Syndrome and Obesity: Targets and Therapy

\author{
Nhu Minh Hang Tran (D) \\ Quang Ngoc Linh Nguyen (D) \\ Thi Han Vo (D) \\ Tran Tuan Anh Le (ID \\ $\mathrm{Ngoc} \mathrm{Ha} \mathrm{Ngo}{ }^{2}$ \\ 'Department of Psychiatry, Hue \\ University of Medicine and Pharmacy, \\ Hue University, Hue, Thua Thien Hue, \\ Vietnam; ${ }^{2}$ Preventive Medicine, Hue \\ University of Medicine and Pharmacy, \\ Hue University, Hue, Thua Thien Hue, \\ Vietnam
}

Background and Aims: Depression is common in people with type 2 diabetes mellitus. The association of depression and diabetes has negative effects on patients. This study investigated the prevalence of depression in individuals with type 2 diabetes mellitus and examined the social, psychological and clinical factors associated with depression.

Patients and Methods: The study included 216 inpatients with type 2 diabetes mellitus at the Department of Endocrinology and Neurology, Hue Central Hospital and the Department of General Internal Medicine, Hue University Hospital. This descriptive cross-sectional study evaluated depression using the Patient Health Questionnaire-9 (PHQ-9). Data were collected on patients' socio-demographic factors such as sex, age, marital and economic status, level of education and clinical factors including duration of type 2 diabetes mellitus, fasting blood glucose, HbA1C, comorbidities or complications as well as health behavior including alcohol consumption, smoking and physical activities. Logistic regression was used to analyze the factors associated with depression in patients with type 2 diabetes mellitus.

Results: $23.2 \%$ of the patients had depression. The rates of severe, moderate and mild depression were $0.5,0.9$ and $21.8 \%$, respectively. Multivariate logistic regression analysis indicated several factors associated with depression in participants, including age under 60 years, poor economic status, unstable or part-time work, having stress during the past year, without/poor treatment adherence to type 2 diabetes mellitus, and engaging in heavy physical activity or physical activity less than three days per week.

Conclusion: The prevalence of depression among patients with type 2 diabetes mellitus is high. Endocrinologists should be made aware of the increased risk of depression in this patient population and screening individuals for relevant risk factors is highly recommended.

Keywords: depression, type 2 diabetes mellitus, prevalence, risk factors

\section{Introduction}

Depression is one of the most common mental health disorders with a lifetime prevalence estimated at approximately $20 \%$ of the worldwide population. According to the World Health Organization (WHO), the global prevalence of depression is about $5 \%$, second only to cardiovascular diseases as the leading cause of functional impairment in patients by the year 2020. Any individual can suffer from depression; however, the risk is higher among those with type 2 diabetes mellitus than in the general population. Previous studies have shown that the prevalence of depression was twofold higher in diabetic patients versus the general population. ${ }^{1}$ In 2018, Khaledi,
Correspondence: Nhu Minh Hang Tran Department of Psychiatry, Hue University of Medicine and Pharmacy, Hue University, 346/I Phan Chu Trinh, Hue,

Thua Thien Hue, Vietnam

$\mathrm{Tel}+84905108019$

Email tnmhang@hueuni.edu.vn
Diabetes, Metabolic Syndrome and Obesity: Targets and Therapy 2021:14 505-5/3

Sumit your manuscript (c) (1) (5) 2021 Iran et al. This work is published and licensed by Dove Medical Press Limited. The full terms of this license are available at https://www.dovepress.com/terms.php BY NC and incorporate the Creative Commons Attribution - Non Commercial (unported, v3.0) License (http://creativecommons.org/licenses/by-nc/3.0/). By accessing the work you hereby accept the Terms. Non-commercial uses of the work are permitted without any further permission from Dove Medical Press Limited, provided the work is properly attributed. For permission for commercial use of this work, please see paragraphs 4.2 and 5 of our Terms (https://www.dovepress.com/terms.php). 
Haghighatdoost, Feizi, Aminorroaya ${ }^{2}$ conducted a meta-analysis of 248 studies around the world $(n=83,020,812$ study participants) and showed that the prevalence of depression in those affected by type 2 diabetes mellitus was $28 \%$. This rate was much higher than the $5 \%$ reported for the general population by WHO. Alajmani, Alkaabi, Alhosaniet al ${ }^{3}$ studied 559 type 2 diabetes mellitus patients in Dubai, United Arab Emirates (UAE) using the Beck Depression Inventory (BDI) and found that the rate of depression in these patients was $17 \%$. In Vietnam, the prevalence of depression was reported to be $25.6 \%$ in a study conducted by Dang, ${ }^{4}$ involving 606 diabetic patients at the center of Endocrinology (Quang Ngai province) using the PHQ-9 score of 9 as a cutoff. The combination of depression and diabetes is an important and complicated public health issue. The causal relationship between depression and diabetes is not well understood. Depression can be not only a cause but also a result of hyperglycemia. Diabetes is a chronic condition with a strict treatment regimen that typically includes adherence to medication, diet, and physical activity. Moreover, diabetes can also lead to many complications including macro- and microvascular diseases, neuropathy, and nephropathy. Diabetes is one of the most common causes of economic burden, comorbidities and an increase in mortality in the world. These factors become a psychological burden for patients, which can lead them down a path towards depression. Furthermore, depressed patients with type 2 diabetes mellitus have worse adherence to dietary, medication, physical inactivity, metabolic and glucose control problems which can exacerbate diabetic complications resulting in disease severity and increasing health-care expenditures, thereby lowering patients' quality of life. There have been several studies on depression in type 2 diabetes mellitus in Vietnam and Hue but the associated factors with depression in type 2 diabetes mellitus were uncertain and different among studies. This study investigated the prevalence of depression in patients with type 2 diabetes mellitus by using PHQ-9 in Hue Central Hospital and Hue University Hospital and examined the risk factors associated with depression in these patients.

\section{Subjects and Methodology Subjects}

A total of 216 patients over 18 years old with type 2 diabetes mellitus, using diagnostic criteria of WHO and Vietnamese Ministry of Health guidelines, were selected from their medical records at the Department of Endocrinology and Neurology, Hue Central Hospital and at the Department of General Internal Medicine, Hue University Hospital from September 2018 to April 2019. These are the two biggest hospitals in Hue city. Patients were invited to enroll in the study if they met the following inclusion criteria: signed the written informed consent form and had the ability to answer the questionnaire. The exclusion criteria were as follows: (1) diagnosis of gestational diabetes mellitus, (2) outpatients, (3) inability to understand Vietnamese, (4) having acute and severe complications such as ketoacidosis, high osmotic pressure coma, (5) having severe chronic diseases or/and severe mental disorders that did not allow the participants to answer the interview questions.

\section{Size of Sample}

The sample size is calculated using the formula for evaluating disorder prevalence in the community.

$$
\mathrm{n}=\left[\mathrm{Z}^{2}(1-\mathrm{a} / 2) * \mathrm{p}(1-\mathrm{p}) / \mathrm{d}^{2}\right.
$$

$\mathrm{n}$ : number of participants, $\mathrm{Z}_{(1-\mathrm{a} / 2)}=1.96$ (confidence interval: $95 \%$ ), $\mathrm{d}: 0.05, \mathrm{p}=12 \%$ (prevalence of depression in patients with type 2 diabetes mellitus in America, in 2013 according to Katon, Young, Russoet $\mathrm{al}^{5}$ ). We estimated that the required sample size for statistical significance must include at least 162 study participants. Eligible participants were selected by convenient sampling technique, and during the time of the study, we selected a total of 216 patients with type 2 diabetes mellitus.

\section{Methods}

\section{Research Design}

This was a cross-sectional study, including descriptive and statistical analyses.

\section{Data Measurement}

The Vietnamese version of PHQ-9 was used to assess depression in the study participants. This instrument consisted of 9 items, a self-administered questionnaire based on the Diagnostic and Statistical Manual of Mental Disorders, 4th edition (DSM-IV) criteria for a major depressive disorder, assessing the patient's mental health status for a 2-week duration, each rated on a 4-point scale ranging with 0 (not at all), 1 (several days), 2 (more than half the days) and 3 (nearly every day). Response options were used to calculate a continuous total score ranging from 0 to 27; scores of 9 or less indicating no depression, 10 to 14 - mild depression, 15 to 19 - moderate depression, and 20 to 27 - severe depression. ${ }^{6}$ PHQ-9 have been used 
Table I Prevalence of Depression According to PHQ-9 Score

\begin{tabular}{|l|l|l|l|}
\hline \multicolumn{2}{|l|}{ Prevalence of Depression by Using PHQ-9 } & Number (n) & Percentage (\%) \\
\hline Without depression & 166 & 76.8 \\
\hline \multirow{2}{*}{ Depression } & Mild & 47 & 21.8 \\
\cline { 2 - 5 } & Moderate & 2 & 0.9 \\
\cline { 2 - 5 } & Severe & 1 & 0.5 \\
\hline Total & & 216 & 100 \\
\hline
\end{tabular}

and adapted in the context of Vietnam with $\alpha$ Cronbach' $s$ alpha ranging from 0.823 to $0.867 .^{7,8}$ To collect risk factors associated with depression, participants used a structured questionnaire on socio-demographic information such as age, gender, occupation, economic, marital status, and level of education, stress events during the past year; and clinical information including duration of diabetes, comorbid diseases and complications, blood pressure, body mass index, and HbAlc; as well as health behavior consisting of smoking, alcohol consumption and physical activities. HbA1c, which reflects the average blood sugar level in the past three months, was recorded from each patient directly after their hospitalization to estimate how well the diabetes has been controlled over the last 3 months. The HbA1C test was done at the biochemistry departments of Hue Central Hospital and Hue University Hospital. Poor blood glucose control was determined by HbA1C over $7 \%$.

To data quality control, research team members were psychiatrists with at least 6 years of experience and were carefully trained in group in the completion of all measures. For all research instruments, the first author trained the others, case studies, role plays and pilot testing were used in training. Besides, for $20 \%$ of interviews, two researchers attended, one as interviewer and the other as observer. And their independent rating was compared. Any difference was discussed with both interviewers.

\section{Statistical Analysis}

All statistical analyses were performed using SPSS version 20.0. Chi-squared tests were applied to measure the difference of characteristics between those with and without depression. The odds ratio (OR) and its 95\% confidence intervals (CIs) were calculated. A p-value $<0.05$ was considered statistically significant. Multivariate logistic regression was employed to identify the potential factors associated with depression among patients with type 2 diabetes mellitus.

\section{Ethics}

Ethics approval was granted by Hue University. This study was conducted in accordance with the Declaration of Helsinki.

\section{Results}

A total of 216 patients with type 2 diabetes mellitus, with the mean age of 64.73 (SD 13.68), 114 women $(52.80 \%)$ and 102 men (47.20\%), participated in the study and completed the questionnaire. Among them, 50 participants (23.20\%) had depression according to the PHQ-9 score in which severe depression was $0.5 \%$, moderate was $0.9 \%$ and mild was $21.8 \%$ (Table 1 ).

Table 2 shows that the prevalence of depression was significantly higher in patients of age under 60 years $(\mathrm{p}<0.01)$, poor economic status $(\mathrm{p}<0.01)$, unstable job vs unemployment $(30.0 \%$ vs $17.7 \%, \mathrm{p}<0.05)$ and stable job vs unemployment $(34,5 \%$ vs $17.7 \%, \mathrm{p}<0.05)$ and having stress events during the past year $(\mathrm{p}<0.01)$. There were no significant differences between the depression group and without depression group in gender, marital status, religion, ethnicity, place of living and level of education ( $\mathrm{p}>0.05)$.

Among clinical characteristics, there was only poor/no adherence to diabetic treatment associated with depression in patients with type 2 diabetes mellitus $(\mathrm{p}<0.05)$, others including BMI, duration of diabetes, glycemic control, comorbid diseases/complication have no association with depression in the participants $(\mathrm{p}>0.05)$ (Table 3 ).

Patients doing heavy physical activities had the highest prevalence of depression among groups $(46,2 \%, \mathrm{p}<0.01)$ and patients doing physical activities less than 3 days have the rate of depression higher than other groups $(50 \%$, $\mathrm{p}<0.01$ ) (Table 4). 


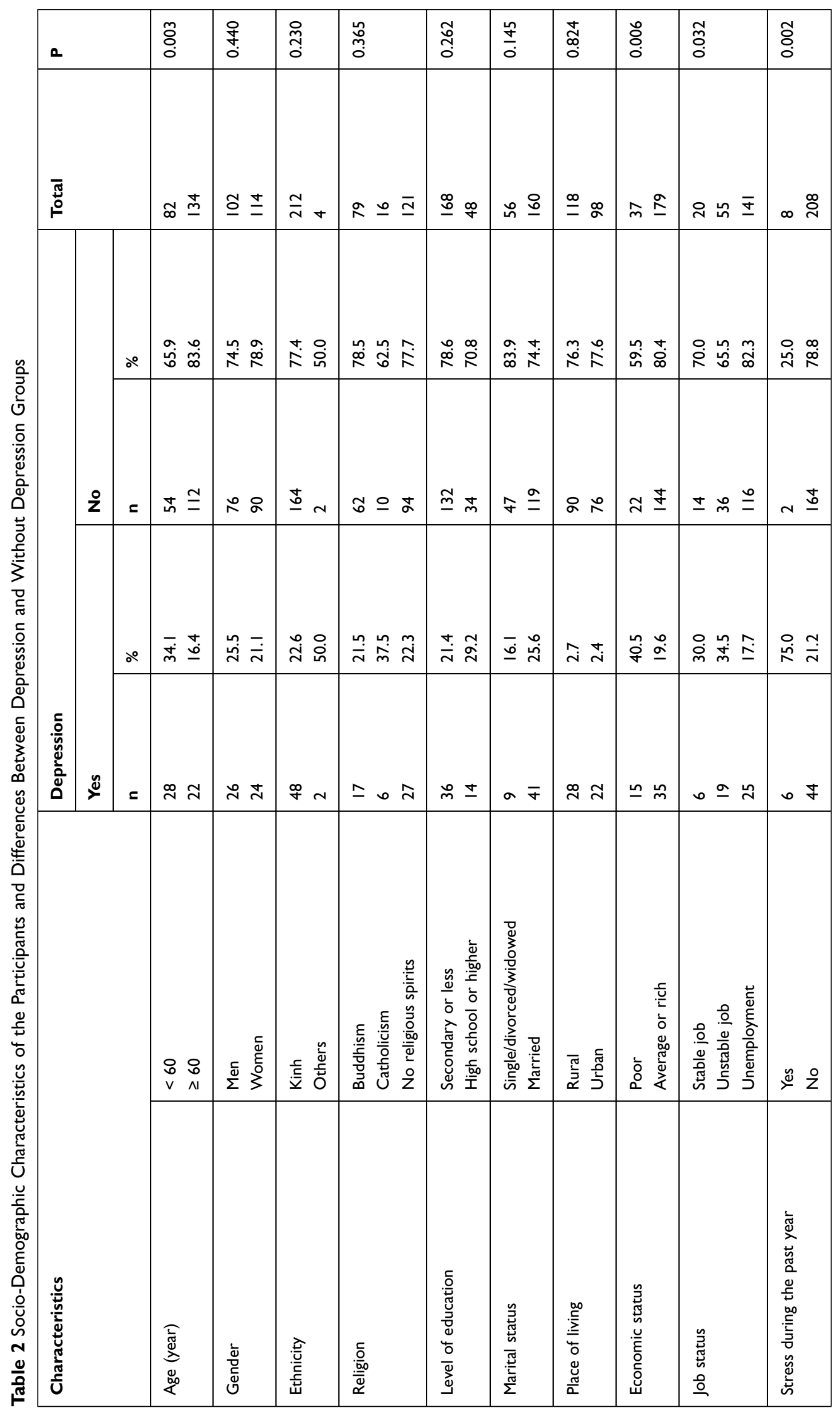




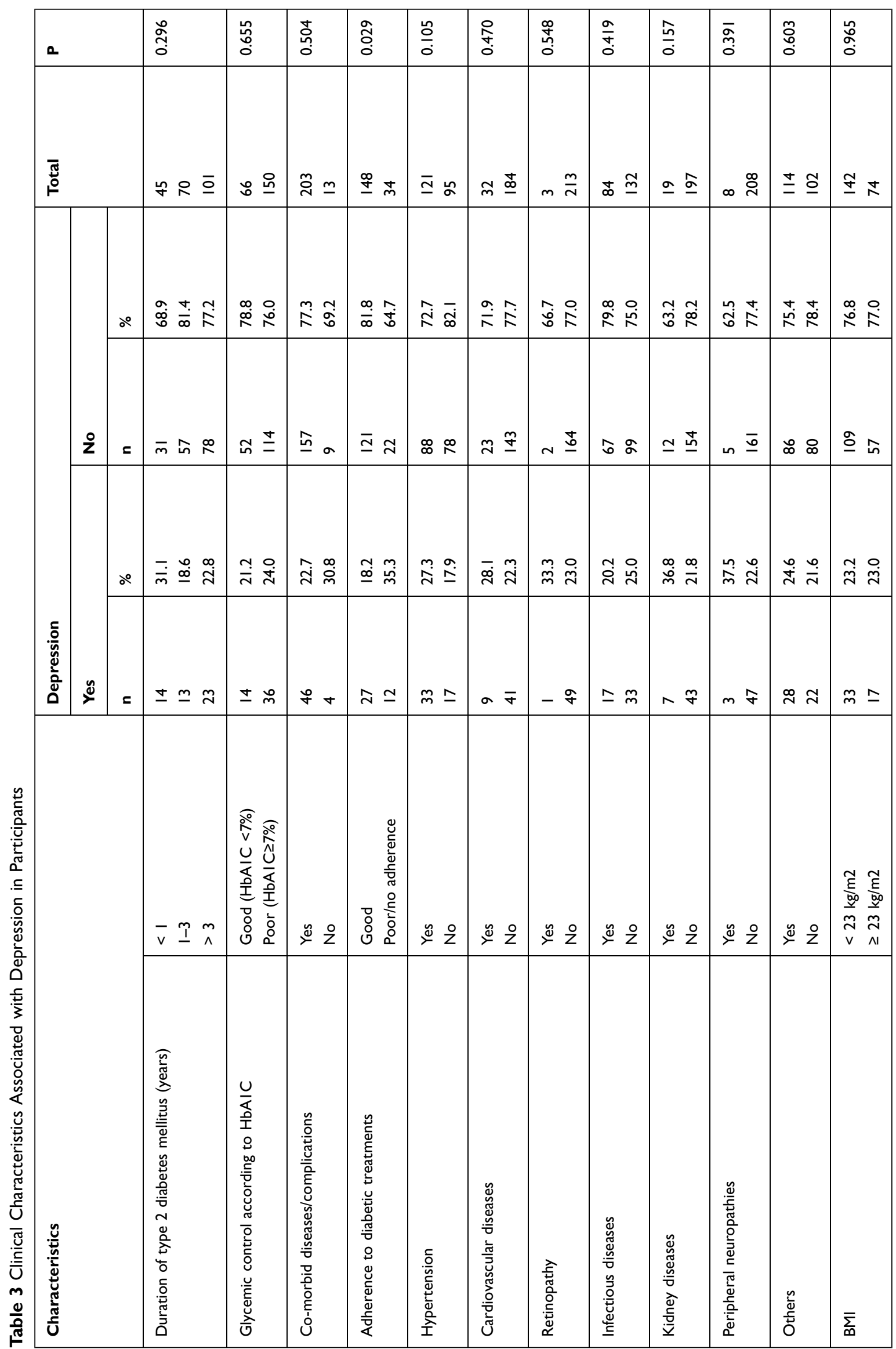


Multivariate logistic regression analysis indicated several factors associated with depression in participants including age under 60 years $(\mathrm{OR}=2.64,95 \% \mathrm{CI}$ : 1.38 5.03, $\mathrm{p}<0.01)$, poor economic status $(\mathrm{OR}=2.8,95 \% \mathrm{CI}$ : $1.32-5.95, \mathrm{p}<0.01)$, unstable or part-time job $(\mathrm{OR}=2.45$, 95\% CI: 1.21-4.95, $\mathrm{p}<0.05)$, having stress during the past year $(\mathrm{OR}=11.18,95 \% \mathrm{CI}: 2.18-57.33, \mathrm{p}<0.01)$, without/ poor treatment adherence with type 2 diabetes mellitus $(\mathrm{OR}=2.44,95 \% \mathrm{CI}: 1.07-5.53, \mathrm{p}<0.05)$, doing heavily physical activity (OR=3.88, 95\% CI: $1.63-9.24, \mathrm{p}<0.01)$, doing physical activity less than 3 days/week $(\mathrm{OR}=4.48$, 95\% CI: 1.80-11.13, $\mathrm{p}<0.01$ ) (Table 5).

\section{Discussion}

The previous studies showed that the prevalence of comorbid depression is high in patients with type 2 diabetes mellitus. ${ }^{1,2,4}$ In this study, we found that $23.2 \%$ of the study population suffered from depression according to PHQ-9 with a cutoff of 10 . The prevalence of depression in type 2 diabetes mellitus varied widely in different countries and studies. Zhang, $\mathrm{Xu}$, Zhaoet $\mathrm{al}^{9}$ studied 2500 patients with type 2 diabetes mellitus in China and showed that the rate of depression in this study was $5.7 \%$ $(142 / 2500)$ according to BDI scores (BDI score $\geq 14)$. The prevalence in an Australian study by Nanayakkara, Pease, Ranasinhaet $\mathrm{al}^{10}$ was $29 \%$ according to the Brief Case find for Depression (BCD). Khaledi, Haghighatdoost, Feizi, Aminorroaya $^{2}$ in their meta-analysis study including 248 studies with 83,020,812 diabetic patients around the world presented that the global prevalence of depression in patients with type 2 diabetes is $28 \%$. In this meta-analysis, Europe (24\%) and Africa (27\%) have a lower depression prevalence than Australia (29\%) and Asia (32\%). The criteria used to determine depression in the studies varied according to the usage of different instruments such as BDI, PHQ-9, Center for Epidemiologic Studies Depression Scale (CESD), Hospital Anxiety and Depression Scale (HADS), DASS-21. ${ }^{2}$ Thus, the difference in the prevalence rate of co-morbid depression in type 2 diabetes mellitus patients among the studies could be explained by using different assessments of depression and even with the same instrument but different cutoff scores for depression.

Our study results showed that the prevalence of depression was significantly higher in patients under 60 years of age $(34.1 \%)$ compared to those $\geq 60$ years old $(16.4 \%)$. This difference was also still present in multivariate logistic regression $(\mathrm{OR}=2.64,95 \% \mathrm{CI}: 1.38-5.03, \mathrm{p}<0.01)$. Our study findings were consistent with those reported in the literature. Katon, Pedersen, Ribeet $\mathrm{al}^{11}$ studied on 2,454,532 patients with type 2 diabetes mellitus and follow up in many years, the results showed that the rate of depression was higher in people under 65 years compared with people from and above 65 years. In another study, $\operatorname{Tran}^{12}$ also found that younger age (under 60 years) is predictor of depression in type 2 diabetes mellitus patients. However, in a meta-analysis study, Roy, Lloyd ${ }^{1}$ reported that the association between age and depression with type 2 diabetes mellitus was uncertain. Several studies revealed that depression occurred more often in patients under 60 years but others showed an inverse relationship. ${ }^{1}$ Younger age, which was one of the predictors of depression in type 2 diabetes mellitus, could be explained by the fact that younger people are less experienced when coping with difficult situations, have more negative influences in many dimensions of their daily life including marital status, working and social functions. These factors could all lead to depression. Besides, it is known that type 2 diabetes mellitus is chronic condition and last for a lifetime so if the younger people get disease the longer duration of illness and the more complications they have in their life. This thought would lead younger people to depression.

Evidence from other study points to poor economic status as significant predictors of depression in both the general population and diabetic patients. ${ }^{13,14}$ In univariate analysis in our study, depression was significantly associated with poor economic status $(\mathrm{p}=0.006)$ (Table 2$)$. In multivariate logistic regression analysis, this risk factor remained significant (OR 2.8, 95\% CI 1.32-5.95, p<0.01) (Table 5).

Unemployment is also a risk factor of depression in several studies. Unemployment was attributed to depression by causing poor economic status, lowering selfesteem. However, we found that patients with an unstable job had a higher rate of depression than those with unemployment $(34.5 \%$ vs $17.7 \%, \mathrm{p}<0.05)$ in single-variate analysis. This difference was also found in multivariate logistic regression $(\mathrm{OR}=2.45,95 \% \mathrm{CI}: 1.21-$ $4.95, \mathrm{p}<0.05)$. We conducted the study in diabetic inpatients so the patients with unstable jobs, they were likely to lose their jobs during hospitalization, making it difficult for them to find work again after discharge. Besides, those were often combined with poor economic status in our study. These would result in them more likely to succumb to depression. Correlation of having stressful events during the past year with depression in patients 
Table 4 Association Between Health Behavior to Depression in the Participants

\begin{tabular}{|c|c|c|c|c|c|c|c|}
\hline \multicolumn{2}{|l|}{ Characteristics } & \multicolumn{4}{|c|}{ Depression } & \multirow[t]{3}{*}{ Total } & \multirow[t]{3}{*}{$\mathbf{P}$} \\
\hline & & \multicolumn{2}{|c|}{ Yes } & \multicolumn{2}{|l|}{ No } & & \\
\hline & & $\mathbf{n}$ & $\%$ & $\mathbf{n}$ & $\%$ & & \\
\hline \multirow[t]{3}{*}{ Smoking cigarettes } & No & 34 & 20.9 & 129 & 79.1 & 163 & 0.349 \\
\hline & Yes & 12 & 31.6 & 26 & 68.4 & 38 & \\
\hline & Now quitting & 4 & 26.7 & 11 & 73.3 & 15 & \\
\hline \multirow[t]{3}{*}{ Drinking alcohol } & No & 42 & 22.3 & 146 & 77.7 & 188 & 0.654 \\
\hline & Yes & 5 & 26.3 & 14 & 73.7 & 19 & \\
\hline & Now quitting & 3 & 33.3 & 6 & 66.7 & 9 & \\
\hline \multirow[t]{4}{*}{ Physical activity } & No & 2 & 28.6 & 5 & 71.7 & 7 & 0.007 \\
\hline & Light & 30 & I8. I & 136 & 81.9 & 166 & \\
\hline & Moderate & 6 & 35.3 & $\mathrm{II}$ & 64.7 & 17 & \\
\hline & Heavy & 12 & 46.2 & 14 & 53.8 & 26 & \\
\hline \multirow[t]{2}{*}{ Duration of physical activity per day } & $\geq 30$ minutes/day & 36 & 25.2 & 107 & 74.8 & 143 & 0.264 \\
\hline & $<30$ minutes/day & 12 & 18.2 & 54 & 81.8 & 66 & \\
\hline \multirow[t]{3}{*}{ Duration of physical activity per week } & Less than 3 days/week & 12 & 50.0 & 12 & 50.0 & 24 & 0.003 \\
\hline & 3-4 days/week & II & 22.9 & 37 & 71.1 & 48 & \\
\hline & $\geq 5$ days/week & 25 & 18.2 & 112 & 81.8 & 137 & \\
\hline
\end{tabular}

with type 2 diabetes mellitus was also found in our study $(\mathrm{OR}=11.18,95 \% \quad \mathrm{CI}: 2.18-57.33, \mathrm{p}<0.01)$. Stressful events could provoke and cause relapses of depression in both the general and diabetic population. Lee, Brazeal, Choiet $\mathrm{al}^{15}$ studied 421 patients with type 2 diabetes mellitus and revealed that the patients with stressful events had higher prevalence of depression than those who had no stressful events. Bădescu, Tătaru, Kobylinskaet $\mathrm{al}^{16}$ also demonstrated similar results. Our study also showed that there were no significant differences between the depressive versus non-depressive groups in gender, marital status, religion, ethnicity, place of living and level of education $(p>0.05)$. Adherence to treatment of diabetes in both dietary and medication was a protective factor in several studies. ${ }^{10,17}$ Treatment adherence treatment improved blood glucose control, reduced diabetic complications, leading to increase quality of life and lower expenditure for health care. We presented that the prevalence of depression in patients with poor adherence to diabetic treatment was significantly higher than that prevalence in patients with good adherence to diabetic treatment $(\mathrm{OR}=2.44,95 \% \mathrm{CI}$ : $1.07-5.53, \mathrm{p}<0.05)$. Practicing and doing exercise and other physical activities were good to the health of normal people and people with type 2 diabetes mellitus. Our study findings showed that duration of physical activities less than 3 days had the highest of prevalence of depression in the participants ( $50 \%$ vs $22.9 \%$ and $18.2 \%$ for rest two groups) (Table 4) $(\mathrm{OR}=4.48,95 \% \mathrm{CI}$ : $1.80-11.13$, $\mathrm{p}<0.01$ ). Doing physical activities heavily was associated with more than a 3-fold increase in the risk of depression in our study $(\mathrm{OR}=3.88,95 \% \mathrm{CI}: 1.63-9.24, \mathrm{p}<0.01)$. Doing physical activities heavily could make patients with chronic disease including diabetes more fatigue, worsen complications or comorbidities especially cardiovascular diseases. So these negative influences could lead patients to depression. The combination of people doing physical activities heavily, poor economic status, and having an unstable job all provoked the onset of depression. BMI, duration of diabetes, glycemic control, comorbid diseases/complications, smoking cigarettes and drinking alcohol had no association with depression in the patient population.

There were limitations to our study. First, we did not use random sample selection but instead used a convenient sample selection technique. Second, some potential variables that could be associated with depression may involve the type and route of medication administration. Finally, we only used the PHQ-9 questionnaire to determine the prevalence of depression as a screening tool and did not use other clinical criteria to definitively diagnose depression. 
Table 5 Multivariate Logistic Regression Model Predicting Co-Morbid Depression (PHQ-9 Score $\geq 10$ ) by Socio-Demographic, Clinical, and Health Behavior Factors

\begin{tabular}{|c|c|c|c|c|}
\hline \multicolumn{2}{|l|}{ Characteristics } & \multirow{2}{*}{$\begin{array}{l}\text { OR } \\
2.64 \\
1\end{array}$} & \multirow{2}{*}{$\begin{array}{l}95 \% \mathrm{Cl} \\
1.38-5.03\end{array}$} & \multirow{2}{*}{$\begin{array}{l}\mathbf{P} \\
0.003\end{array}$} \\
\hline Age (years) & $\begin{array}{l}<60 \\
\geq 60\end{array}$ & & & \\
\hline Economic status & $\begin{array}{l}\text { Poor } \\
\text { Average or rich }\end{array}$ & $\begin{array}{l}2.8 \\
1\end{array}$ & $1.32-5.95$ & 0.007 \\
\hline Job status & $\begin{array}{l}\text { Stable job } \\
\text { Unstable/part time job } \\
\text { Unemployment }\end{array}$ & $\begin{array}{l}1.98 \\
2.45 \\
1\end{array}$ & $\begin{array}{l}0.69-5.68 \\
1.21-4.95\end{array}$ & $\begin{array}{l}0.199 \\
0.013\end{array}$ \\
\hline Stress events during the past year & $\begin{array}{l}\text { Yes } \\
\text { No }\end{array}$ & $\begin{array}{l}11.18 \\
1\end{array}$ & $2.18-57.33$ & 0.004 \\
\hline Physical activity & $\begin{array}{l}\text { Lightly } \\
\text { No } \\
\text { Moderately } \\
\text { Heavily }\end{array}$ & $\begin{array}{l}1 \\
1.81 \\
2.47 \\
3.88\end{array}$ & $\begin{array}{l}0.33-9.79 \\
0.84-7.21 \\
1.63-9.24\end{array}$ & $\begin{array}{l}0.489 \\
0.097 \\
0.002\end{array}$ \\
\hline Adherence to diabetic treatment & $\begin{array}{l}\text { Good } \\
\text { Poor/no adherence }\end{array}$ & $\begin{array}{l}1 \\
2.44\end{array}$ & $1.07-5.53$ & 0.032 \\
\hline Duration of physical activity per week & $\begin{array}{l}\text { Less than } 3 \text { days/week } \\
3-4 \text { days/week } \\
\geq 5 \text { days/week }\end{array}$ & $\begin{array}{l}4.48 \\
1.33 \\
1\end{array}$ & $\begin{array}{l}1.80-11.13 \\
0.59-2.96\end{array}$ & $\begin{array}{l}0.001 \\
0.483\end{array}$ \\
\hline
\end{tabular}

\section{Conclusion}

The prevalence of depression is high in patients with type 2 diabetes mellitus. Multivariate logistic regression analysis indicated several factors associated with depression in participants including age under 60 years, poor economic status, unstable or part-time job, having stress during the past year, without/poor treatment adherence with type 2 diabetes mellitus, doing heavy physical activity, or doing physical activity less than three days per week.

Given the high prevalence of depression among patients with type 2 diabetes mellitus, awareness of depression in type 2 diabetes mellitus should be raised among endocrinologists. Screening patients with type 2 diabetes mellitus for co-morbid depression and its risk factors is also recommended.

\section{Acknowledgments}

The authors wish to thank the patients and the hospital staff who participated and facilitated us in the study.

\section{Funding}

This research was supported by Hue University (grant number: DHH-04-80).

\section{Disclosure}

The authors have no conflict of interest to declare.

\section{References}

1. Roy T, Lloyd CE. Epidemiology of depression and diabetes: a systematic review. J Affect Disord. 2012;142:S8-S21. doi:10.1016/ S0165-0327(12)70004-6

2. Khaledi M, Haghighatdoost F, Feizi A, Aminorroaya A. The prevalence of comorbid depression in patients with type 2 diabetes: an updated systematic review and meta-analysis on huge number of observational studies. Acta Diabetol. 2019;56(6):631-650.

3. Alajmani DSA, Alkaabi AM, Alhosani MW, et al. Prevalence of undiagnosed depression in patients with type 2 diabetes. Front Endocrinol (Lausanne). 2019;10:259. doi:10.3389/fendo.2019.00259

4. Dang T. Nghiên cưu tỷ lệ trầm cảm và một số yếu tố liên quan ở bệnh nhân đái tháo đuờng típ 2 điều trị ngoại trú tại trung tâm nội tiết tỉnh Quảng Ngãi năm 2019 [Thesis for the specialist level two program]. Hue, Vietnam: Hue University Of Medicine and Pharmacy; 2019.

5. Katon WJ, Young BA, Russo J, et al. Association of depression with increased risk of severe hypoglycemic episodes in patients with diabetes. Ann Fam Med. 2013;11(3):245-250. doi:10.1370/afm.1501

6. Kroenke K, Spitzer RL, Williams JBW. The PHQ-9: validity of a brief depression severity measure. J Gen Intern Med. 2001;16(9):606-613. doi:10.1046/j.1525-1497.2001.016009606.x

7. Dang DT. Đánh giá sơ bộ giá trị của bảng hỏi sức khỏe bệnh nhân (PHQ -9) trong sàng lọc Bệnh nhân Trầm cảm. J Pract Med. 2011;774 (7):173-176.

8. Tam NT. Assessing validity of patient health questionnaire- 9 in detecting depression in community setting in Khanh Hoa and Danang provinces. PHQ-9 Valid Rep. 2009;1-25. 
9. Zhang W, Xu H, Zhao S, et al. Prevalence and influencing factors of co-morbid depression in patients with type 2 diabetes mellitus: a general hospital based study. Diabetol Metab Syndr. 2015;7(1):60. doi:10.1186/s13098-015-0053-0

10. Nanayakkara N, Pease A, Ranasinha S, et al. Depression and diabetes distress in adults with type 2 diabetes: results from the Australian national diabetes audit (ANDA) 2016. Sci Rep. 2018;8(1):7846. doi:10.1038/s41598-018-26138-5

11. Katon W, Pedersen HS, Ribe AR, et al. Effect of depression and diabetes mellitus on the risk for dementia: a national populationbased cohort study. JAMA Psychiatry. 2015;72(6):612-619. doi:10.1001/jamapsychiatry.2015.0082

12. Tran THA. Nghiên cúu đặc điểm lâm sàng trầm cảm và một số yếu tố liên quan ở bệnh nhân đái tháo đuờng type 2 [PhD thesis]. Hanoi, Vietnam: Hanoi Medical University; 2018.

13. Park CY, Kim SY, Gil JW, Park MH, Park J-H, Kim Y. Depression among korean adults with type 2 diabetes mellitus: ansan-community-based epidemiological study. Osong Public Health Res Perspect. 2015;6(4):224-232. doi:10.1016/j.phrp.2015.05.004
14. Camara A, Baldé NM, Enoru S, Bangoura JS, Sobngwi E, Bonnet F. Prevalence of anxiety and depression among diabetic African patients in Guinea: association with HbA1c levels. Diabetes Metab. 2015;41 (1):62-68. doi:10.1016/j.diabet.2014.04.007

15. Lee J, Brazeal M, Choi H, Rehner TA, McLeod ST, Jacobs CM. Physical and psychosocial factors associated with depression among adults with type 2 diabetes mellitus at a federally qualified healthcare center. Soc Work Health Care. 2018;57(10):834-850. doi:10.1080/ 00981389.2018.1508113

16. Bădescu SV, Tătaru C, Kobylinska L, et al. The association between diabetes mellitus and depression. J Med Life. 2016;9(2):120-125.

17. Mendes R, Martins S, Fernandes L. Adherence to medication, physical activity and diet in older adults with diabetes: its association with cognition, anxiety and depression. J Clin Med Res. 2019;11 (8):583-592. doi:10.14740/jocmr3894

Diabetes, Metabolic Syndrome and Obesity: Targets and Therapy

\section{Publish your work in this journal}

Diabetes, Metabolic Syndrome and Obesity: Targets and Therapy is an international, peer-reviewed open-access journal committed to the rapid publication of the latest laboratory and clinical findings in the fields of diabetes, metabolic syndrome and obesity research. Original research, review, case reports, hypothesis formation, expert opinion and commentaries are all considered for publication. The manuscript management system is completely online and includes a very quick and fair peer-review system, which is all easy to use. Visit http://www.dovepress.com/testimonials.php to read real quotes from published authors. 